\title{
Characterization of Rhizobacteria from Field Grown Genetically Modified (GM) and Non-GM Maizes
}

\author{
Emmanuel Wihkochombom Bumunang and Olubukola Oluranti Babalola* \\ Department of Biological Sciences; Faculty of Agriculture; Science and Technology; North-West University; \\ Mafikeng Campus; Mmabatho - South Africa
}

\begin{abstract}
This study was done to examine the rhizobacteria from field grown Genetically Modified (GM) maize and its nonGM counterpart. Rhizospheric soil samples were collected at 30 days after sowing (DAS) and at post-harvest from two experimental fields in Gauteng, South Africa. Total rhizobacteria (cfu/g) in GM and non-GM soil samples was not significantly different across the different media $30 \mathrm{DAS}$ and at post-harvest. Rhizobacterial isolates obtained were biochemically characterized using the analytical profile index. Species of Pseudomonas, Aeromonas, Sphingomonas, Burkholderia, Stenotrophomonas, Achromobacter, Ewingella and Bacillus were screened in vitro for plant growth promoting traits such as, ammonia production, catalase activity, indole acetic acid production, phosphate solubilisation, hydrogen cyanide production and antifungal activity. All the 32 rhizobacterial strains tested in this study were positive for catalase activity, ammonia production and IAA production; $90.6 \%$ were positive for phosphate solubilisation, $34.3 \%$ for indicate antifungal activity but none for hydrogen cyanide production. These findings contributed to the quest for potential biofertilizers and biocontrol agents for sustainable agriculture.
\end{abstract}

Key words: Genetically modified maize, Plant growth promoting traits, Rhizosphere, Rhizobacteria

\section{INTRODUCTION}

Plant-microbe interaction occurs in the rhizosphere, a region referred to as a biological active zone of soil where microorganisms and plant roots interact, and is of major importance for plant growth as well as for the nutrient cycling and ecosystem (Babalola 2010). The rhizoplane or the root surface provides a highly favorable nutrient base and attachment site for many bacteria. However, in response to this microbial habitat and the nutrients provided by the plant, some microbes assist the plant by making nutrients available, while some may cause harm to the plant by acting as root pathogens (Anton et al. 2006). Kloepper and Schroth (1978) introduced the term plant growth promoting rhizobacteria (PGPR), referring to the bacteria capable of colonizing the plant root, or rhizosphere promoting plant growth. The PGPR can be divided into two groups according to their residing site, iPGPR (symbiotic bacteria) which live inside the plant cells, produce nodules and are localized inside those specialized structures, and ePGPR (free living rhizobacteria), which live outside the plant cells and do not produce nodules, but still prompt the plant growth (Gray and Smith 2005). Species of Pseudomonas, Azospirilum, Azotobacter, Klebsiella, Bacillus, Arthrobacter, Alcaligenes, Serratia, Rhizobium, Beijerinckia, Zoogloea, Sinorhizobium and Mesorhizobium have been reported to promote plant growth directly or

*Author for correspondence: olubukola.babalola@nwu.ac.za 
indirectly (Esitken et al. 2003; Babalola 2010). The mechanism of action of the PGPR in the promotion of plant growth are not fully understood, but are thought to include the synthesis of phytohormones and lytic enzymes at the level of plant root (Gray and Smith 2005), antagonism against pathogenic microbes at the level of roots by the production of siderophores (Dey et al. 2004), induce host resistance to pathogenic microbes (Van loon 2007), asymbiotic fixation of nitrogen (Sahin et al. 2004) and the synthesis of antibiotics (Debbelaere et al. 2002). Bacillus thuringiensis (Bt) maize (a genetically modified maize) contains insecticidal toxic proteins (Bt endotoxins) that has advantages for crop production, such as increased insect resistance, grain yield and plant growth (Obrycki et al. 2001). These $\mathrm{Bt}$ endotoxins could be introduced in the rhizosphere through root exudates (Saxena et al. 2002) and could possibly affect the rhizobacterial community structure. Root exudates in the root-soil interface create a unique microbial microenvironment, differentiating it from the bulk soil not influenced by the roots (Hartman et al. 2006; Babalola 2010). Furthermore root exudates quality and quantity vary with the plant developmental stage and plant species determining the microbial community structure (Berg et al. 2002; Babalola 2007). Different rhizosphere populations have been reported in different plant species at different plant growth stages (Somers et al. 2004). According to Brusetti et al. (2004), microbial community associated with the rhizospheres of $\mathrm{Bt}$ maize differs from its non-Bt maize. In contrast, Devare et al. (2004) found that genetic modification of maize had no effect on the microbial communities in the rhizosphere. However, concerns about possible effects of genetically modified (GM) maize root exudates on rhizobacteria species and population needs to be considered.

Various studies have been carried out globally to isolate and screen the rhizobacteria for plant growth trait. Literature with regards to PGPR from genetically modified maize and its non-GM counterpart is rare. Coupled with the idea that GM plants could release high root exudate due to increase rate of photosynthesis, this study attempted to isolate and characterize the PGPR in field grown GM maize and its non-GM counterpart. A good knowledge and understanding of the different species and their mechanism in plant growth promotion could be used in sustainable agriculture.

\section{MATERIALS AND METHODS}

\section{Isolation and characterization}

Soil samples of field grown GM and non-GM maize were collected from two experimental fields in Gauteng, South Africa 30 days after the sowing (DAS) and at post-harvest. Sixteen soil samples were collected in triplicate; eight from the GM maize area and the other eight from the non-GM maize area.

One gram of soil sample of field grown GM and non-GM maize was transferred into test tubes with $9.0 \mathrm{~mL}$ of distilled water. Serial dilutions up to $10^{-6}$ were made using distilled water. A volume of $0.5 \mathrm{~mL}$ of each dilution was plated by spread plate technique on tryptic soy agar (TSA), nutrient agar (NA), Luria Bertani agar (LBA) (non-selective media for general isolation of culturable bacteria) and Pseudomonas selective agar (PSA). The plates were incubated at $28^{\circ} \mathrm{C}$ for two to three days. Bacterial growth was recorded as colony forming units (cfu). Colonies were randomly selected and biochemically identified using the analytical profile index (API), followed by in vitro characterization for plant growth promoting traits.

\section{Genomic DNA extraction}

Rhizobacterial isolates from the GM and non-GM soil samples were grown overnight in nutrient broth and genomic DNA was extracted by the hexadecyltrimethy-lammonium bromide (CTAB) method (Doyle and Doyle 1990). The bacterial 16S rDNA primer Ps-for (5'GGTCTGAGAGGATGATCAGT3') and Ps-rev (5'TTAGCTCCACCTCGCGGG3') as well as universal primer $27 \mathrm{~F}$ (5'AGAGTTTGATCCTGGCTCAG3') and 1492R (5'TGACTGACTGAGACTACCTTGTTACGA3') were used to amplify 989 bp and 1500 bp of the $16 \mathrm{~S}$ rDNA gene region. Polymerase chain reaction (PCR) was done using a DNA Engine DYAD ${ }^{\mathrm{TM}}$ Peltier Thermal Cycler. Thermal cycling were performed as follows: Initial denaturation at $94^{\circ} \mathrm{C}$ for $5 \mathrm{~min}$, followed by 30 cycles of $94^{\circ} \mathrm{C}$ for 1 min, $55^{\circ} \mathrm{C}$ for $1 \mathrm{~min}, 72^{\circ} \mathrm{C}$ for $1.5 \mathrm{~min}$ and final extension at $72^{\circ} \mathrm{C}$ for $8 \mathrm{~min}$. The fragments obtained were analyzed by gel electrophoresis $(24$ $\times 12 \mathrm{~cm}$ ) with $1 \%$ agarose, and carried out at $80 \mathrm{~V}$ for $2 \mathrm{~h}$. A 1-kb gene ladder loaded on the left lane 
of the gel was used as a molecular size marker. The gel was then stained with ethidium bromide and digital picture of amplified gene was taken under UV light using a G: BOX SYNGENE. The PCR products were sent to Inqaba laboratory in Pretoria for sequencing. Sequence search for the alignment of nucleotides was performed using the BLAST (Basic Local Alignment Search Tool) web-based program (Altschul et al. 1990).

\section{Production of Indole Acetic Acid (IAA)}

IAA production was detected as described by (Brick et al. 1991). Freshly grown cultures in the nutrient broth amended with tryptophan and incubated at $36 \pm 2^{\circ} \mathrm{C}$ for $48-72 \mathrm{~h}$ were centrifuged at $7500 \mathrm{x} \mathrm{g}$ for $30 \mathrm{~min}$. After which, $2.0 \mathrm{~mL}$ of the supernatant was mixed with two drops of $10 \mathrm{mM}$ orthophosphoric acid and $4.0 \mathrm{~mL}$ of the Salkowski reagent $(50 \mathrm{~mL}, 35 \%$ of perchloric acid, $1.0 \mathrm{~mL}$ $0.5 \mathrm{M} \mathrm{FeCl}_{2}$ solution). The mixture was incubated at room temperature for $25 \mathrm{~min}$. The development of pink colour indicated the production of IAA.

\section{Production of Ammonia}

Freshly grown cultures of the isolates were inoculated in $10 \mathrm{~mL}$ of peptone water in a tube and incubated for $48-72 \mathrm{~h}$ at $36 \pm 2^{\circ} \mathrm{C}$. After which, 0.5 $\mathrm{mL}$ of Nessler's reagent was added in the tube. The development of brown to yellow colour was a positive test for ammonia production (Cappuccino and Sherman 1992).

\section{Catalase Production}

Catalase test was done by adding a drop of 3\% hydrogen peroxide to freshly grown bacterial isolate on a sterile slide using a sterile wire loop. The effervescence indicated catalase activity.

\section{Antifungal Activity}

Antifungal activity was tested using the method of Mehnaz and Lazarovits (2006). Test bacterial isolates were co-inoculated on potato dextrose agar (PDA) containing the fungal pathogen and incubated at $27^{\circ} \mathrm{C}$ for five days. Antibiotic production against the pathogen was observed as a zone of growth inhibition around the tested bacterial isolate.

\section{Phosphate Solubilization}

Qualitative assay for phosphate solubilization was performed using Pikovskaya medium containing tricalcium phosphate (Pikovskaya 1948). Bacterial culture were streaked on the medium and incubated at $30^{\circ} \mathrm{C}$ for $48 \mathrm{~h}$. The presence of a clear halo zone around the culture spot indicated phosphate solubilization capacity of the isolate.

\section{Production of Hydrogen Cyanide (HCN)}

Freshly grown isolates were screened for $\mathrm{HCN}$ production by adapting the method of (Lorck 1948). Isolates grown in nutrient broth amended with $4.4 \mathrm{~g}$ glycine/L were streaked on the modified nutrient agar plate. A sterile Whatman filter paper no. 1 soaked in $2.5 \%$ sodium carbonate in $0.5 \%$ picric acid solution was placed at the top of the plate. Plates were sealed with parafilm and incubated at $36 \pm 2^{\circ} \mathrm{C}$ for four days. Change of yellow colour on Whatman filter paper to orangered colour indicated $\mathrm{HCN}$ production.

\section{RESULTS AND DISCUSSION}

Total rhizobacteria cfu/g of GM and non-GM soil samples across the different media is presented in Figure 1. There was no significant difference in the rhizobacterial population between the GM and non-GM soil sample either at 30 DAS, or at postharvest. However, plate count for Pseudomonas selective medium at post-harvest indicated a significant decrease in the rhizobacterial population when compared to the population at 30 DAS. Based on the API identification, similar bacterial species were identified in the GM and non-GM maize rhizosphere (Table 1). However, different rhizosphere species were identified at 30 DAS and at post-harvest from PSA. P. putida, $P$. stutzeri and A. denitrificans were identified in the soil samples at 30 DAS. The post-harvest identification indicated species of Burk. cepacia and $A$. denitrificans in the GM and non-GM with no species of Pseudomonas.

In this study, species of Pseudomonas, Aeromonas, Sphingomonas, Burkholderia, Stenotrophomonas, Achromobacter, Bacillus and Ewingella isolated from maize rhizosphere (GM and non-GM) were tested in vitro for the plant growth promoting traits (Table 2). Of the 32 rhizobacterial strains tested in this study, all strains were positive for catalase activity, ammonia production and IAA production; $90.6 \%$ were positive for phosphate solubilisation, 34.3\% indicated antifungal activity but none were positive for hydrogen cyanide production. There was no significant difference in the $\mathrm{pH}$ levels of soil samples (GM and non-GM) 30 DAS and at 
post-harvest (Table 3). Loam soil was used in this study.

The amplification of the genomic DNA from the rhizobacterial isolates using the universal $16 \mathrm{~S}$ primers (25F and 1492R) and Pseudomonas primers (Ps-for and Ps-rev) yielded DNA fragments with band sizes of 1.5 and $1.0 \mathrm{~kb}$ (Figs.
2 and 3). The sequence analysis of Gram-positive rhizobacterial isolates from the GM and non-GM maize rhizosphere are shown in Table 4. The rhizobacteria isolates EW51, EW62, EW66, EW68, EW6, EW5, and EW35 belonged to $B$. cereus, Bacillus spp, B. aryabhattai, B. pumilus, $B$. megaterium, $B$. thuriengiensis and $B$. safensis.
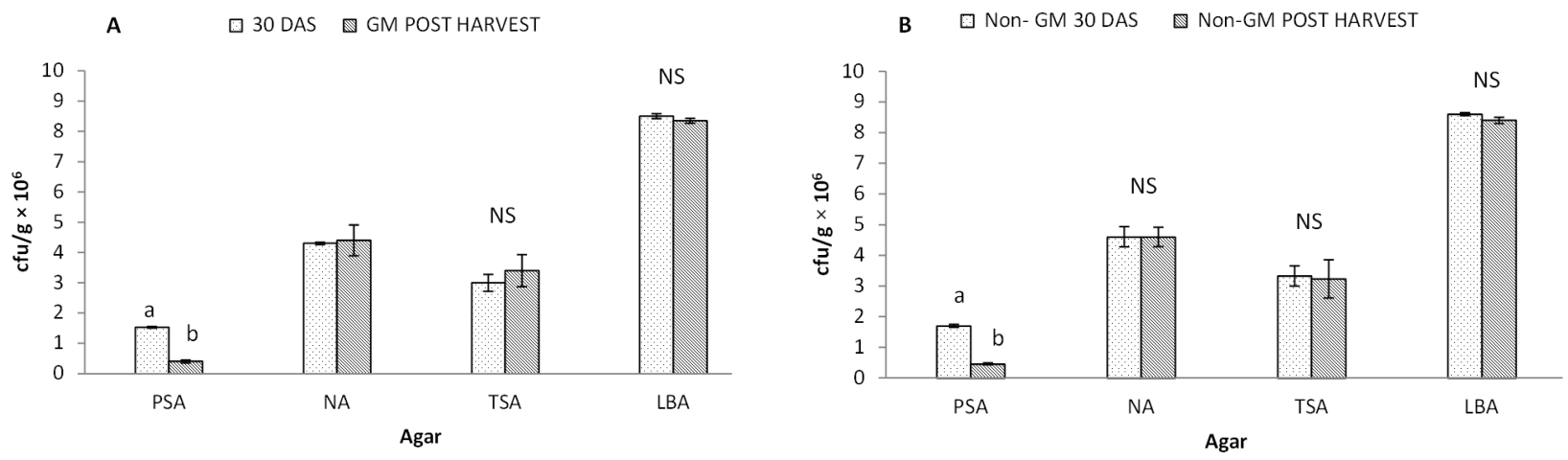

Figure 1 - Total rhizobacterial cfu/g of soil on Pseudomonas selective agar (PSA), nutrient agar (NA), tryptic soy agar (TSA) and Luria Bertani agar (LBA) from field grown Genetically Modified (GM) and non-GM maize soil samples 30 DAS and at post-harvest. Bars represent standard error of the mean of three replicates. The bars with similar letters are not significantly different at $\mathrm{P} \geq 0.05$ using analysis of variance.

NS: means not significant.

Table 1 - Identification of rhizobacterial isolates recovered at 30 DAS (days after sowing) and at post-harvest using analytical profile index (API).

\begin{tabular}{|c|c|c|c|}
\hline Source & Time of collection & Medium & Species obtained \\
\hline \multirow[t]{8}{*}{ GM } & $30 \mathrm{DAS}$ & NA & S. paucimobilis, Sten. maltophilia, P. luteola \\
\hline & & TSA & S. paucimobilis, Burkholderia cepacia. \\
\hline & & LBA & S. paucimobilis, P. luteola, Burkholderia cepacia \\
\hline & & PSA & P. putida, A. denitrificans \\
\hline & Post-harvest & NA & S. paucimobilis, Sten. Maltophilia, Burkholderia cepacia \\
\hline & & TSA & S. paucimobilis, P. stutzeri \\
\hline & & LBA & S. paucimobilis, Aeromonas hydrophila/caviae \\
\hline & & PSA & Burk.cepacia, A. denitrificans \\
\hline \multirow[t]{8}{*}{ Non-GM } & $30 \mathrm{DAS}$ & NA & S. paucimobilis, $P$. luteola, Sten. maltophilia \\
\hline & & TSA & S. paucimobilis, Sten. maltophilia \\
\hline & & LBA & S. paucimobilis, Burkholderia cepacia \\
\hline & & PSA & P. stutzeri, A. denitrificans \\
\hline & Post-harvest & NA & S. paucimobilis, Burkholderia cepacia \\
\hline & & TSA & S. paucimobilis, E. americana \\
\hline & & LBA & S. paucimobilis, Ent. coacae \\
\hline & & PSA & Burkholderia cepacia, A. denitrificans \\
\hline
\end{tabular}

$\overline{\mathrm{GM}}=$ genetically modified; Non-GM $=$ Non genetically modified 
Table 2 - Plant growth promoting traits of rhizobacterial isolates from genetically modified (GM) and non-GM maize rhizosphere.

\begin{tabular}{|c|c|c|c|c|c|c|c|}
\hline Source & Bacteria (no of strain) & $\begin{array}{c}\text { Antifungal } \\
\text { activity }\end{array}$ & $\begin{array}{l}\text { Catalase } \\
\text { activity }\end{array}$ & $\begin{array}{l}\text { Ammonia } \\
\text { production }\end{array}$ & $\begin{array}{c}\text { IAA } \\
\text { production }\end{array}$ & $\begin{array}{c}\mathrm{HCN} \\
\text { production }\end{array}$ & $\begin{array}{c}\text { Phosphate } \\
\text { solubilization }\end{array}$ \\
\hline \multirow[t]{7}{*}{ GM } & P. luteola (3) & + & + & + & + & - & + \\
\hline & Aero. hyrophila (1) & - & + & + & + & - & - \\
\hline & Sten. maltophilia (1) & - & + & + & + & - & + \\
\hline & B. thuringiensis (1) & + & + & + & + & - & - \\
\hline & P. putida (2) & - & + & + & + & - & + \\
\hline & S. paucimobilis (3) & + & + & + & + & - & + \\
\hline & Burk. cepacia (3) & - & + & + & + & - & + \\
\hline \multirow[t]{9}{*}{ Non-GM } & A. xylosoxidans (1) & - & + & + & + & - & + \\
\hline & S. paucimobilis (3) & + & + & + & + & - & + \\
\hline & Bur. cepacia (3) & - & + & + & + & - & + \\
\hline & Sten. maltophilia (1) & - & + & + & + & - & + \\
\hline & E. americana (1) & - & + & + & + & - & + \\
\hline & P. stutzeri (3) & - & + & + & + & - & + \\
\hline & P. putida (3) & - & + & + & + & - & + \\
\hline & B. thuringiensis (1) & + & + & + & + & - & - \\
\hline & B. safensis (2) & - & + & + & + & - & + \\
\hline
\end{tabular}

$+=$ Positive reaction, $-=$ Negative reaction

Table 3 - pH results of Genetically Modified (GM) and non-GM maize rhizosphere soil samples. The results represent the mean of three replicates \pm standard error.

\begin{tabular}{lll}
\hline Source & $\begin{array}{l}\text { Period of } \\
\text { collection }\end{array}$ & $\begin{array}{l}\text { pH values } \\
\text { mean } \pm \text { standard error }\end{array}$ \\
\hline GM & 30 DAS & $6.74^{\mathrm{a}} \pm 0.04$ \\
& Post-harvest & $6.78^{\mathrm{a}} \pm 0.16$ \\
Non-GM & 30 DAS & $7.03^{\mathrm{a}} \pm 0.06$ \\
& Post-harvest & $6.12^{\mathrm{a}} \pm 0.59$ \\
\hline
\end{tabular}

Means followed by same letters are not significantly different at $\mathrm{P} \geq 0.05$ using analysis of variance.

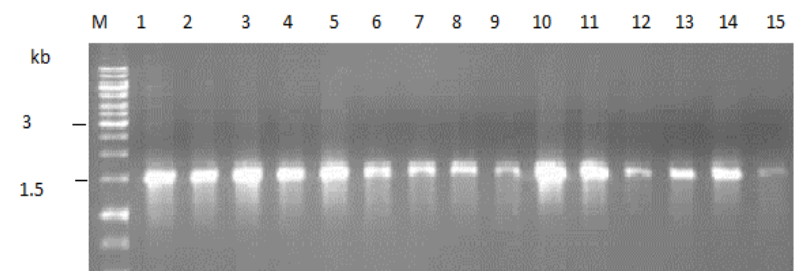

Figure 2 - Electrophoresis gel in agarose (1\%) of PCR products amplified from GM and non-GM soil samples from nutrient agar (NA), Pseudomonas selective agar (PSA), trypticase soy agar (TSA) and Luria Bertani agar (LBA). Lane M, 1-kb DNA ladder, lane 1-3 Bacillus thuringiensis, lane 4-5 B. safensis, lane 6-9 Sphingomonas paucimobilis, lane 10 Sten. maltophilia, lane 11 Aero. hyrophila, lane $12 \mathrm{~A}$. xylosoxidans, lane 13 E. americana, lane 14 Burk. cepacia and lane 15 P. luteola.

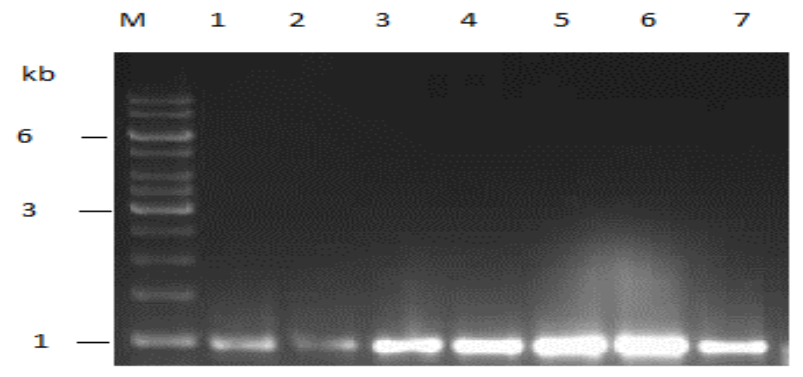

Figure 3 - Electrophoresis in agarose gel (1\%) of PCR products amplified from Genetically Modified (GM) and non-GM soil samples from Pseudomonas selective media. Lane M, 1-kb DNA ladder, lane 1-3 Pseudomonas putida and lane 4-7 Pseudomonas Stutzeri.

Table 4 - Sequence analysis of rhizobacterial isolates from GM and non-GM maize rhizosphere.

\begin{tabular}{lcccc}
\hline Source & $\begin{array}{c}\text { Isolate } \\
\text { number }\end{array}$ & Description & $\begin{array}{c}\text { \% } \\
\text { Identity }\end{array}$ & $\begin{array}{c}\text { Accession } \\
\mathbf{n}^{\mathbf{0}} .\end{array}$ \\
\hline GM & EW51 & B. cereus & 100 & JX317637 \\
& EW62 & Bacillus spp. & 99 & AB736322 \\
& EW66 & B. aryabhattai & 100 & JX293286 \\
& EW68 & B. pumilus & 100 & HQ625388 \\
\hline Non-GM & EW6 & B. megaterium & 100 & JX393073 \\
& EW5 & B. & 99 & JX283457 \\
& \multicolumn{3}{c}{ thuriengiensis } \\
& EW35 & B. safensis & 99 & JX094951 \\
\hline
\end{tabular}


The PGPR make up a diverse group of rhizosphere-colonizing bacteria in association with the plant roots, which promote growth of the plant. According to Cattelan et al. (1999), PGPR should be able to survive and colonize the rhizosphere. Their colonizing ability has been attributed to plant species (Garbeva et al. 2004) and antagonistic potentials (Berg et al. 2002).

In this study, identified species were able to survive in the maize rhizosphere 30 DAS and at post-harvest. The no significant difference in rhizobacterial population in the maize rhizosphere of GM and non-GM at 30 DAS and at post-harvest did not comply with the idea that GM plants could exhibit high photosynthetic activity and as a result release more root exudates resulting to higher microbial population in the rhizosphere.

S. paucimobilis, Sten. maltophilia, Burk. Cepacia, P. putida, and Bacillus spp obtained in this study have been reported in the maize rhizosphere (Chelius and Triplett 2000; Mehnaz and Lazarovits 2006; Mehnaz et al. 2007). These findings could be of significance because species of B. cepacia and Sten. maltophilia isolated in this study have been described as opportunistic human pathogens (Berg et al. 2005) where they could cause lung infections and bacteraemia, Therefore, future prospects in biotechnological applications needs further considerations.

Changes in the rhizosphere species throughout the developmental stages of the plants have been documented and attributed to changes in root exudates quality and quantity (Berg et al. 2002) According to Kapoor et al. (2012), plant age and nutrient exhaustion throughout the plant developmental stage could lead to a decrease in Pseudomonas population in the rhizosphere. These were in agreement with the present results, which indicated different rhizobacteria species be at 30 DAS, or at post-harvest using Pseudomonas selective medium. The persistence of Burk. cepacia throughout the maize developmental stages in this study correlated with the findings of Di Cello et al. (1997) who reported an increase in Burk. cepacia population throughout the season in maize rhizosphere at different plant growth stages. Catalase activity is an important trait of bacteria as it helps the bacteria to protect itself against hydrogen peroxide, a poisonous compound to bacteria and plant roots. Therefore, PGPR with catalase activity will survive in the rhizosphere and promote plant growth indirectly. All the rhizobacterial strains in this study were catalase positive, correlating with earlier studies (Babu et al. 2007; Chaiharn et al. 2008). IAA a phytohormone, which controls root elongation and cell division in the plants, is produced from tryptophan by the process of decarboxylation and transamination (Khan et al. 2009). Sources of IAA other than those produced by the plants can also contribute to the morphological changes at the level of root system influencing the uptake of nutrients by the plant (San Francisco et al. 2005). In this study, all the rhizobacterial strains tested produced IAA in nutrient broth amended with tryptophan, and therefore, complied with the studies of Ahemad and Mohammad (2010) and Marques et al. (2010).

Similarly ammonia production was evident by all the bacteria isolates. Ammonia production is an important trait of PGPR, which promotes plant growth indirectly. Only the strains of $S$. paucimobilis and $P$. luteola showed antifungal activity against $F$. oxysporum a plant pathogen. This activity was read as zone of inhibition and could have contributed the dominance ability of $S$, paucimobilis in the rhizosphere of the GM and non-GM maize throughout the growing season. $P$. luteola antifungal activity in this study complied with that of Bano and Musarrat, (2003) and in combination with Sphingomona species could serve as potential biocontrol agents in the promotion of plant growth.

Phosphorous (P) is the second most important nutrient required by the plants for the growth compared to nitrogen (Pradhan and Sukla 2006). Podile and Kishore (2007) referred to phosphate solubilising bacteria as the bacteria capable of secreting phosphatases and organic acids, which converts the insoluble phosphate to soluble monobasic and dibasic ions. Rhizobacteria exhibiting this process makes phosphorous available for the plant uptake at the level of plant root (Gyaneshwar et al. 2002). In this study, the rhizobacterial isolates from the rhizosphere of the GM and non-GM maize were screened for phosphate solubilizing activity by the spot plate inoculation method on Pikovskaya's medium containing tricalcium phosphate. Phosphate solubilization was expressed in terms of clear zone produced around the bacterial strain. Of the 32 rhizobacterial strains tested, $90.6 \%$ were positive for phosphate solubilization. Therefore, rhizobacteria strains in this study were capable of solubilizing the mineral $\mathrm{P}$ in the rhizosphere hence, provided soluble $\mathrm{P}$ to plants. 
Cynogenic activity (HCN production) by the rhizobacteria has been suggested to play a significant role in the biological control of pathogens (Voisard et al. 1989). The production of $\mathrm{HCN}$ by the rhizobacterial strains into the rhizosphere has been reported (Devi et al. 2007). In this study, all the rhizobacterial strains tested for cynogenic activity were negative. Results indicated that the bacterial strains could not induce resistance to plant from the antibiosis.

In this study, most rhizobacterial isolates showed four plant growth promoting traits, confirming that the PGPR strains were capable of expressing the multiple beneficial functions (Kloepper and Schrot 1978). However, in vivo screening and synergic biotechnological application are required for further confirmation as plant growth promoters.

\section{CONCLUSIONS}

In this study, most rhizobacterial isolates from the GM and non-GM maize rhizosphere showed four plant growth promoting traits, confirming that the PGPR strains were capable of expressing the multiple beneficial functions (Kloepper and Schrot 1978). However, in vivo screening and synergic biotechnological application of the PGPR as plant growth promoters are required for further confirmation. Therefore, considering the fact that PGPR are eco-friendly with regards to the misuse of chemical fertilizer and pesticide, which are not friendly to native soil rhizobacteria and environment puts PGPR as a better alternative to chemical fertilizers and pesticides.

\section{ACKNOWLEDGMENTS}

We acknowledge the collection of samples by $\mathrm{Dr}$ E. Barros. This work is based upon research supported by the National Research Foundation.

\section{REFERENCES}

Ahemad M, Mohammad SK. Plant growth promoting activities of phosphate-solubilizing Enterobacter asburiae as influenced by fungicides. EurAsia J BioSci. 2010; 4: 88-95.

Altschul SF, Gish W, Miller W, Myers EW, Lipman DJ. "Basic local alignment search tool." J Mol Biol. 1990; 215:403-410.
Anton H, Kornelia S, Jan S. Microbial diversity in the rhizosphere: Highly resolving molecular methodology to study plant-beneficial rhizosphere bacteria. In: Gero B, Sylvia S, editors. Biodiversity in agricultural production systems Florida: CRC Press; 2006, p. 101-130.

Babalola OO, Sanni AI, Odhiambo GD, Torto B. Plant growth-promoting rhizobacteria do not pose any deleterious effect on cowpea and detectable amounts of ethylene are produced. World J Microbiol Biotechnol. 2007; 23: 747-752.

Babalola OO. Beneficial bacteria of agricultural importance. Biotechnol Lett. 2010; 32: 1559-1570.

Babu J, Ranjan RP, Rubina L. Characterization of plant growth promoting rhizobacteria associated with chickpea (Cicer arietinum L.). Int J Plant Prod. 2007; 2: 141-152.

Bano N, Musarrat J. Characterization of a new Pseudomonas strain NJ-15 as a potential biocontrol agent. Curr Microbiol. 2003; 46: 324-328.

Berg G, Eberl L, Hartmann A. The rhizosphere as a reservoir for opportunistic human pathogenic bacteria. Environ Microbiol. 2005; 7(11): 1673-1685.

Berg G, Roskot N, Steidle A, Eberl L, Zock A, Smalla K. Plant-dependent genotypic and phenotypic diversity of antagonistic rhizobacteria isolated from different verticillium host plants. Appl Environ Microbiol. 2002; 68: 3328-3338.

Brick JM, Bostock RM, Silversone SE. Rapid in situ assay for indole acetic acid production by bacteria immobilization on a nitrocellulose membrane. Appl Environ Microbiol. 1991; 57: 535-538.

Brusetti L, Francia P, Bertolini C, Pagliuca A, Borlini S, Sorlini C, et al. Bacterial communities associated with the rhizosphere of transgenic $\mathrm{Bt} 176$ maize (Zea mays) and its non-transgenic counterpart. Plant and Soil. 2004; 266: 11-12.

Cappuccino JC, Sherman N. Negative staining. In: Cappuccino JC, Sherman N, editors Microbiology: A Laboratory Manual. Benjamin/Cummings: Redwood City; 1992. p. 125-179.

Cattelan AJ, Hartel PG, Fuhrmann JJ. Screening of plant growth promoting rhizobacteria to promote early soybean growth. Soil Sci Soc Am J. 1999; 63: 16701680.

Chaiharn M, Chunhaleuchanon S, Kozo A, Lumyong S. Screening of rhizobacteria for their plant growth promoting activities. Sci Technol J. 2008; 1: 18-23.

Chelius MK, Triplett EW. Immunolocalization of dinitrogenase reductase produced by Klebsiella pneumoniae in association with Zea mays L. Appl Environ Microbiol. 2000; 66: 783-787.

Devare JS, Jones CM, Thies JE. Effects of Cry3Bb transgenic corn and tefluthrin on the soil microbial community: biomass, activity, and diversity. J Environ Qual. 2004; 33: 837-843.

Devi KK, Seth N, Kothamasi S, Kothamasi D. Hydrogen cyanide-producing rhizobacteria kill subterranean termite Odontotermes obesus (rambur) by cyanide poisoning under in vitro conditions. Curr Microbiol. 2007; 54: 74-78. 
Dey R, Pal KK, Bhatt DM, Chauhan SM. Growth promotion and yield enhancement of peanut (Arachis hypogaea L) by application of plant growth-promoting rhizobacteria. Microbiol Res. 2004; 159: 371-394.

Di Cello F, Bevivino A, Chiarini L, Fani R, Paffetti D, Tavacchioni S, et al. Biodiversity of a Burkholderia cepacia population isolated from the maize rhizosphere at different plant growth stages. Appl Environ Microbiol. 1997; 63: 4485-4493.

Dobbelaere S, Croonenborghs A, Thys A, Ptacek D, Okon Y, Vanderleyden J. Effects of inoculation with wild type Azospirillum brasilense and A-irakense asrains on development and nitrogen uptake of spring wheat and grain maize. Biol Fert Soil. 2002; 36: 284-297.

Doyle JJ, Doyle JL. Isolation of plant DNA from fresh tissue. Focus. 1990; 12: 13-15.

Esitken A, Karlidag H, Ercisli S, Turan M, Sahin F. The effects of spraying a growth promoting bacterium on the yield, growth and nutrient element composition of leaves apricot Prunus armeniaca L. Aust J Agr Res. 2003; 54: 377-380.

Garbeva P, Van Veen, JA, Van Elsas JD. Microbial diversity in soil: selection of microbial populations by plant and soil type and implications for disease suppressiveness. Ann Rev Phytopathol. 2004; 42: 243270.

Gray EJ, Smith DL. International and extracellular PGPR: commonalities and distinction in the plant bacterium signalling processes. Soil Biol Biochem. 2005; 37: 395412.

Gray EJ, Smith DL. International and extracellular PGPR: commonalities and distinction in the plant bacterium signaling processes. Soil Biol and Biochem. 2005; 37: 395-412.

Gyaneshwar P, Kumar GN, Parekh LJ, Poole PS. Role of soil microorganisms in improving phosphate nutrition of plants. Plant and Soil. 2002; 245: 83-93.

Hartman A, Smalla K, Jan S. Microbial diversity in the rhizosphere: Highly resolving molecular methodology to study plant-beneficial rhizosphere bacteria. In: Benckiser $G$ and Schnell S, editors. Biodiversity in agricultural production systems. Florida: CRC Press; 2006. p. 101-130.

Kapoor RR, Kumar A, Kumar A, Patil S, Thapa S, Kaur M. Evaluation of plant growth promoting attributes and lytic enzyme production by fluorescent Pseudomonas diversity associated with apple and pear. Int J Sci Res Publ. 2012; 2: 2250-3153.

Khan MS, Zaidi A, Wani PA, Ahemad M, Oves M. Functional diversity among plant growth-promoting rhizobacteria. In: Khan MS, Zaidi A, Musarrat J, editors. Microbial strategies for crop improvement. Berlin: Springer; 2009. p. 105-132.

Kloepper JW, Schrot M. Plant growth promoting rhizobacteria on radishes. Prot Int Conf Plant Pathog Bact. 1978; 2: 879-882.

Lorck H. Production of hydrocyanic acid by bacteria. Plant Physiol. 1948; 1: 142-146.
Marques APC, Pires C, Moreira H, Rangel AO, Castro PML. Assessment of the plant growth promotion abilities of six bacterial isolates using Zea mays as indicator plant Soil Biol Biochem. 2010; 42: 1229-1235.

Mehnaz S, Lazarovits G. Inocuation effect of Pseudomonas putida, Gluconacetobacter diazotrophicus and Azospirillum lipoferum on corn plant growth under greenhouse conditions. Microbiol Ecol. 2006; 51: 326335.

Mehnaz S, Weselowski B, Lazarovits G. Sphingobacterium canadense sp. nov, an isolate from corn roots. Syst Appl Microbiol. 2007; 30: 519-524.

Obrycki JJ, Losey JE, Tayler OR, Jesse LC. Transgenic insecticidal corn: beyond insecticidal toxicity to ecological complexity. Bioscience. 2001; 51: 353-361.

Pikovskaya RI. Mobilization of phosphorous in soil in connection with vital activity of some microbial species. Microbiologica. 1948; 17: 362-370.

Podile AR, Kishore GK. Plant growth-promoting rhizobacteria: In Gnanamanickam SS, editor: Plantassociated bacteria. Springer, P.O Box 17, 3300 AA Dordrecht. The Netherlands; 2007. p. 195-230.

Pradhan N, Sukla LB. Solubilization of inorganic phosphate by fungi isolated from agriculture soil. Afr $J$ Biotechnol. 2006; 5: 850-854.

Sahin F, Cakmakci R, Kantar F. Sugar beet and barley yields in relation to inoculation with $\mathrm{N}_{2}$-fixing and phosphate solubilizing bacteria. Plant Soil. 2004; 265: 123-129.

San Francisco S, Houdusse F, Zamarreno AM, Garnica M, Casanova E, Garcia- Mina JM. Effects of IAA and IAA precursors on the development, mineral nutrition, IAA content and free polyamine content of pepper plants cultivated in hydroponic conditions. Sci Hortic. 2005; 106: 38-52.

Saxena D, Flores S, Stotzky G. Bt toxin is released in root exudates from 12 transgenic corn hybrids representing three transformation events. Soil Biol Biochem. 2002; 34: 133-137.

Singh BK, Milard P, Whitely AS, Murrell JC. Unravelling rhizosphere microbial interactions: opportunities and limitations. Trends Microbiol. 2004; 12: 386-393.

Somers E, Vanderleyden J, Srinivisam M. Rhizosphere bacterial signalling: a love parade beneath our feet. Crit Rev Microbiol. 2004; 30: 205-240.

Van Loon LC. Plant response to plant growth-promoting rhizobacteria. Eur J Plant Pathol. 2007; 119: 243-254.

Voisard C, Keel C, Haas D, Defago G. Cyanide production by Pseudomonas fluorescens helps suppress black root rot of tobacco under gnotobiotic conditions. EMBOJ. 1989; 8: 351-358.
Received: October 11, 2012; Accepted: June 11, 2013. 